\title{
Keteladanan dalam Konteks Kepemimpinan Nasional dan Realitas Kemajemukan Bangsa
}

\author{
Faisal Ismail
}

Indonesian constitutes a pluralistic nation and that of society. The pluralities of Indonesian consist of either horisontal or vertical. This nation needs a national leader who has a good qualified, for instance inclusivce and pluralisric leader. The leader does not only reach position of power but also he or she has capability, integrity, visioneer how to manage the pluralistic nation of indonesia. The power for leader must return to the people in term of intellectuality, prosperous, social justice and peace that in accordace with trusteed by Allah.

$\mathrm{B}$ angsa Indonesia ditakdirkan sebagai sebuah bangsa dengan corak masyarakat yang plural (pluralistic society). Pluralitas masyarakat Indonesia ditandai dengan ciri yang bersifat horisontal dan vertikal. Ciri horisontal terlihat pada kenyataan adanya kesatuan-kesatuan sosial yang berdasarkan perbedaanperbedaan suku bangsa, agama, adat serta kedaerahan. Kemajemukan ini disebabkan oleh beberapa faktor, seperti keadaan geografis, dimana wilayah Indonesia yang terbagi menjadi 13.767 pulau merupakan faktor yang sangat besar pengaruhnya kepada terciptanya pluralistik suku bangsa Indonesia.

Faktor kedua adalah letak Indonesia yang berada di antara dua benua dan diapit oleh samudera Indonesia dan samudera pasifik. Tentu hal ini sangat berpengaruh terhadap terciptanya geopolifik dan geokultur Indonesia. Faktor ketiga adalah kondisi alam dan struktur tanah yang berbeda-beda di antara berbagai daerah kepulauan, sehingga menciptakan pola dan cara hidup serta tradisi yang tidak sama.

Ciri vertikal adalah gambaran lain struktur masyarakat Indonesia yang berbentuk perbedaan-perbedaan lapisan sosial antara lapisan atas dan lapisan bawah. Pelapisan sosial yang bersifat kentara tersebut terlihat pada sejumlah orang berdasarkan kemampuan dan penguasaan yang bersifat ekonomis, politis, ilmu pengetahuan, dan sebagainya. Sebagian orang, dalam hal ini, berada pada posisi yang lemah atau berada pada lapisan bawah, sementara sejumlah kecil lainnya, yakni orang kaya, yang "berkuasa", dan yang terdidik berada pada lapisan atas.

Melihat struktur masyarakat Indonesia, yang seperti itu, jelas merupakan suatu gambaran kemajemukan yang menunjukkan perbedaan-perbedaan dan derajad sosial, sehingga berpotensi sebagai salah satu sumber konflik. Lebih rumit lagi, jika 
kemajemukan pelapisan sosial ini berbenturan dengan pengelompokan horisontal masyarakat, maka konflik yang eksesif seringkali tidak dapat dielakkan. Konflik tersebut sangat menghambat upaya pembangunan masyarakat sejahtera, bahkan dapat mengancam integritas nasional bangsa.

Beberapa tahun belakangan, bangsa Indonesia menghadapi peristiwa konflik antar kelompok di beberapa tempat. Berbagai peristiwa tersebut selain mengindikasikan terjadinya pertentangan menyangkut berbagai kepentingan diantara kelompok masyarakat yang plural tersebut, juga menggambarkan terjadinya krisis keteladanan dalam kepemimpinan masyarakat.

Akibat lebih jauh, selain tidak segera dapat dipulihkan berbagai pertikaian masyarakat dan munculnya ancaman terhadap integritas bangsa, konflik tersebut juga membawa negeri ini terperosok kian jauh ke dalam kondisi ketertinggalan dan martabatnya semakin rendah de tengahtengah percaturan antar bangsa-bangsa dunia. Dalam situasi demikian tentu kehadiran pemimpin teladan sangat didambakan untuk segera membawa bangsa ini keluar dari krisis berkepanjangan menuju masa depan yang lebih gemilang.

\section{Kriteria Pemimpin Masyarakat Majemuk}

Pemimpin teladan dalam konteks masyarakat majemuk adalah pemimpin yang memiliki karakter, sikap, visi, dan orientasi yang senantiasa mengedepankan nilai-nilai kebersamaan di atas kepentingan pribadi, kelompok atau golongan. Dengan sifat-sifat seperti ini, seorang pemimpin dapat juga disebut sebagai seorang negarawan (meskipun tidak mengemban posisi formal kenegaraan). Dengan ciri yang demikian seorang pemimpin teladan senantiasa berkomitmen untuk memberikan yang terbaik bagi bangsa dan negara, bahkan kemanusiaan universal melalui bidang pengabdian atau profesi yang ditekuninya.

Dari fenomena yang dialami bangsa Indonesia akhir-akhir ini semakin jelas terlihat bahwa krisis keteladanan telah melanda berbagai aspek kepemimpinan. Fenomena sosial menunjukkan bahwa banyak rakyat yang bingung memahami para pemimpinnya. Pemimpin yang seyogyanya harus dapat memberikan ketenteraman, keteladanan atau contoh yang baik untuk ditiru, tetapi dalam kenyataan di beberapa tempat, kentara sekali bahwa para pemimpin lebih memperhatikan pada urusanurusan yang lebih mengamankan kepentingan pribadi atau kelompok dari pada berlapang hati bekerjasama berjuang mengatasi berbagai masalah demi ketentraman serta kemajuan bersama.

Salah satu kendala mencolok terwujudnya karakter pemimpin teladan adalah power oriented yang obsesif. Tendensi yang ada pada sebagian pemimpin adalah cenderung memperluas pengikut dari pada meningkatkan kualitas. Dengan kata lain lebih senang mengoleksi sumberdaya dan mengakumulasikannya sendiri untuk merebut atau mempertahankan kekuasaan daripada mengkonsolidasikannya untuk meningkatkan potensi bersama bagi kepentingan masa depan.

Jika para pemimpin masih terbelenggu dengan obsesi kekuasaan semata dan kurang fokus pada pencapaian cita-cita nasionał, maka bangsa ini akan sulit bangkit menjadi bangsa yang kuat, serta akan selalu kalah bersaing dalam kompetisi global. Hanya dengan kepemimpinan yang teladaniah matarantai keterpurukan akan dapat diputuskan dan bangsa ini dapat 
keluar dari krisis multi demensi sekaligus melangkah ke arah kemajuan yaing lebih gemilang di masa yang akan datang.

\section{Menciptakan Pemimpin Teladan}

Mengingat pentingnya peran pemimpin teladan bagi kemajuan suatu bangsa, maka upaya menumbuhkan calon pemimpinpemimpin teladan nasional ke depan merupakan focus yang tidak kalah penting dibanding barbagai fokus nasional lainnya. Segala formula menyangkut rencanarencana perbaikan dan kebajikan dalam gaung reformasi menjadi tidak bermakna manakala faktor keteladanan diabaikan. Sebab, intisari dari kepemimpinan adalah"memandu jalan dan membawa orang lain sampai ketujuan bersama".

Oleh karena itu, senantiasa penting dikritisí apakah seorang calon pemimpin memiliki kemempuan memandu jalan bagi masyarakat majemuk untuk sampai ke tujuan bersama atau justru dirinya sendiri berjalan dalam kegelapan visi, misi dan integrasi. Dengan kata lain, seorang Pemimpin tidak akan mampu membawa orang lain ke suatu tujuan, jika dirinya sendiri tidak dapat memberikan contoh yang baik. Jika demikian, maka sesungguhnya persoalan pemimpin teladan ini esensinya adalah penyiapan SDM yang berkualitas.

Untuk mengatasi persoalan SDM sebagai andalan masa depan, BJ Habibie pernah melontarkan pendapat, yakni manakala ilmu pengetahuan, pendidikan, budaya (termasuk Agama) mendapat perhatian utama. Dalam proses pembudayaan, seseorang semestinya menerima transfer nilai-nilai bududaya dan agama yang cukup. Sehingga yang bersangkutan kelak kemudian diharapkan memiliki perilaku sopan, berbudaya, bermoral, beretika dan mempunyai integritas pribadi yang kuat.
Sementara itu, lewat proses pengetahuan seseorang dapat memiliki wawasan luas, memahami perbedaan-perbedaan serta kesamaan-kesamaan masyarakat, memiliki budaya bebas berpikir, mampu meniliai yang terbaik, dapat dikritik dan mengkritik. Adapun lewat proses pendidikan, memungkinkan seseorang dapat memahami dan memiliki dasar ilmu pengetahuan dan teknologi yang dibutuhkan untuk menjadi terampil dan andal.

Dengan memperhatikan aspek-aspek tersebut diharapkan kelak akan muncul pemimpin-pemimpin bangsa yang memiliki daya teladan yang kuat, sehingga senantiasa memiliki komitmen untuk memperjuangkan cita-cita bersama yang besar, yakni kepentingan bangsa dan negara. Dengan bekal itu, seseorang juga diharapkan menjadi pemimpin yang selalu ingin mendidik rakyat menjadi cerdas, bukan hanya cerdas otak, tetapi juga cerdas hidup, yang tahu harkat dan martabat, tidak rendah diri, namun berkarakter kuat.

\section{Penutup}

Semoga pasca Pemilu 2004, muncul figur pemimpin nasional yang memiliki kualifikasi pemimpin teladan. Pemimpin yang demikian bukan sekedar pejabat yang memperoleh posisi/kekuasaan, melainkan karena kemampuan, integritas, dan daya visioner yang tinggi untuk mengelola bangsa yang sangat majemuk ini. Kekuasaan bagi pemimpin seperti ini adalah mengembalikannya pada sang pemilik (rakyat) dalam bentuk kecerdasan, kesejahteraan, keadilan sosial, dan kedamaian sesuai amanat Allah SWT, Tuhan Yang Maha Esa, sang Pencipta dan Pemilik Kekuasaan Tertinggi. 
Topik: Kepemimpinan Nasional Pasca Pemilu 2004

\section{Daftar Pustaka}

Ahmad, Nur, Ed. 2001, Pluralisme Agama: Kerukunan dan Keagamaan. Jakarta: Kompas.

A'la, Abd.2002, Melampaui Dialog Agama. Jakarta: Kompas.

Ali, Mursyid, (ed.) 2000, Hak-hak Asasi Manusia dan Keutuhan Bangsa. Jakarta: Badan Litbang Agama, Departemen Agama:
Ali, Mursyid, (ed). , 2000, Konflik Sosial: Demokrasidan Rekonsiliasi Menurut Perspektif Agama-agama. Jakarta: Badan Litbang Agama Departemen Agama.

Hidayat, Komaruddin. Et,al. , 2002, Agama di Tengah Kemelut. Jakarta: Media Cinta.

Ismail, Faisal , 2002, Pijar-pijar Islam: Pergumulan Kultur dan Struktur. Yogyakarta: LESFI. 